Cahiers d'études africaines

\title{
Subordinate Black South African Men without Fear
}

Homme noir subordonné et sans peur en Afrique du Sud

\section{Kopano Ratele}

\section{OpenEdition}

\section{Journals}

\section{Electronic version}

URL: http://journals.openedition.org/etudesafricaines/17320

DOI: 10.4000/etudesafricaines. 17320

ISSN: $1777-5353$

\section{Publisher}

Éditions de l'EHESS

\section{Printed version}

Date of publication: 28 May 2013

Number of pages: $247-268$

ISBN: 978-2-7132-2387-7

ISSN: 0008-0055

\section{Electronic reference}

Kopano Ratele, "Subordinate Black South African Men without Fear », Cahiers d'études africaines [Online], 209-210 | 2013, Online since 06 June 2015, connection on 10 December 2020. URL : http:// journals.openedition.org/etudesafricaines/17320 ; DOI : https://doi.org/10.4000/etudesafricaines. 17320

This text was automatically generated on 10 December 2020.

(c) Cahiers d'Études africaines 


\title{
Subordinate Black South African Men without Fear
}

\author{
Homme noir subordonné et sans peur en Afrique du Sud
}

\author{
Kopano Ratele
}

1 South Africa has relatively high homicide rates (Krug et al. 2002; Bradshaw et al. 2003; Groenewald et al. 2008; Donson 2009; Seedat et al. 2009; South African Police Service [SAPS] 2010; United Nations Office on Drugs and Crime [UNODC] 2011). Research studies and police reports for the country indicate that homicide in South Africa is overwhelmingly a male enterprise, an effect of violence undertaken against males by other males. Young males, and specifically Black or African ${ }^{1}$ young men, are the most likely common victims, a pattern found in other countries with significant Black populations (Covington 2003; Hawkins 2003; Olivier 2003). This vulnerability to homicidal $^{2}$ victimization of young Black South African men is the main concern of this paper. The major question underlying the paper is why nearly two decades after the fall of apartheid does the risk for premature violent death remain high amongst young Black males?

2 The main contention of the paper is that the high levels of Black male homicide victimisation can be better understood by paying attention to the role of the emotions, alongside structural and symbolic facts, in the construction and performance of Black young masculinities. The paper starts by summarizing the magnitude, distributions and patterns of homicide in South Africa as a backcloth to an exploratory discussion on young Black men's vulnerability to deadly violence. Given the attention it has received within the field of critical studies of men and masculinity, the next section problematizes hegemonic masculinity as an explanation of Black male homicide. I argue that in the context of historically powerless race groups or subordinate classes, some men appear to be simultaneously positioned as hegemonic and subordinate. Therefore, to employ the concept of hegemonic masculinity tout court in trying to understand Black men is not always useful as some Black masculinities may simultaneously be prevalent and subordinate positionings. 
3 The paper then looks at the role of emotion in violence victimization and constructions of manhood. It traces negative emotions in the history and politics of South Africa, as well as their role in shaping forms of Black masculinity. Without underplaying the social power of men in relation to women, I suggest that it is crucial to seek to understand the relationship between Black men's vulnerability to fatal violence and their emotional existence. The paper centres on the possible linkages between fear and psychosocial insecurity on one hand, and fearlessness, anger and rage on the other, in the construction of young African masculinity in South Africa. Thus I argue for a better appreciation of emotions in trying to understand the heightened vulnerability of young African men to dying from violence. I show how critical studies on Black men's violence against other men (and women) have to analyse the role social and economic justice, but are likely to fail in helping efforts to understand deadly violence where they do not account for the emotional (and more generally psychological) health and politics of Black young masculinities.

\section{Homicide in South Africa in Brief}

4 Violence in all its forms is said to claim between 1 and 2 million lives every year globally and over $90 \%$ of lives lost occur in low-and middle-income countries (Matzopoulos et al. 2008). It is estimated that, globally 31\% of violent deaths in 2000 and $34 \%$ of violent deaths in 2001 were a result of homicide (Rosenberg et al. 2006). While it has declined from the high of the mid-1990s, homicidal violence remains stubbornly high in post-apartheid South Africa. The rates for homicidal violence for the country are higher than most countries. The latest crime report of the South African police indicates 15,609 murders and 14,859 attempted murders for the period 2011-2012 (respectively 30.9 and 29.4 per 100,000 population) (SAPS 2012). The figures for 2010-2011 were $15,940(31.9 / 100,000)$ and $15,493(31.0 / 100,000)$ (ibid. 2011). The country's homicide rate makes it country "among the most violent in the world" (Norman et al. 2007). The Global Study on Homicide underlines the high rates in the country and offers an explanation for these: "South Africa, a country with a high homicide rate, displays a pattern of lethal male violence similar to the Americas, with (the) highest shares of homicide victims in the age groups between 20 and 39. This is a pattern of male violence that owes much to the types of risk-seeking behaviour in which certain disadvantaged groups in South African society routinely engage" (UNODC 2011: 68).

5 Violence is shown to be among the leading causes of premature death in the country. A comparison of households in different racial categories showed that Black households had a higher experience of violent death (Doolan et al. 2007). Seedat et al. (2009: 1012) observed that "a dominant feature of violence in South Africa is the disproportionate role of young men as perpetrators and victims. The highest homicide victimization rates are seen in men aged 1,529 years $(184$ per 100,000) and in some areas, for instance in Cape Town's townships, rates are more than twice this number. Deaths of men from homicide outnumber those of women by more than 7:1. The male to female ratio increases further for deaths during the evening: two of every three male violent deaths occur at night". Seedat et al. (ibid.) are incorrect that "although most homicide victims are Black, the highest rates are reported in men and women who under apartheid were classified as Coloured" (Groenewald et al. 2008; Ratele 2011a). 
Similar to other countries, then, levels of death from interpersonal violence in the country are not evenly distributed across age-groups and sex/gender. Homicide risk is differentiated according to race, city, neighbourhoods, and province, among other factors. According to Ratele and associates (2011a), for instance, the highest rates of interpersonal violence-related fatalities in South Africa are observed among older teenagers and young adult males in African race groups in poor and low-income neighbourhoods within the Cape Town metropolitan area. The highest rates in Cape Town were seen among Black males aged between 20 and $24(501.6 / 100,000)$. The rates of death from interpersonal violence amongst young adult Black males are approximately 16 times the highest rates of Capetonian white males-among whom the highest rates are observed in the age group 35-39 (31.7/100,000). After Black males, coloured males in Cape Town have the next highest rates of homicidal victimisation. In this group the highest rates are for those aged between 25 and 29 (196.7/100,000). The rates are more than twice as low as rates for Black males but still considerably higher than the highest rates for whites and Asians/Indians.

Other South African studies have also shown significant differences in death from homicide between males and females, with the largest difference in homicide rates indicated for Cape Town. For instance, in 2006, the most recent peak year in homicide rates, overall there were 123.9/100,000 fatal interpersonal deaths among males and 11.9/100,000 deaths among females (Groenewald et al. 2008; Ratele et al. 2011a). A similar picture obtains for other large South African cities: although some cities have smaller gaps, men generally, but African young men specifically, tend to die at higher rates than females.

In general then, on average more young people than older people, more Blacks than other groups, more males than females, more people from poor and low-income neighbourhoods, more people in metros than in the more rural municipalities, more people in Cape Town than Johannesburg, and more people in predominantly urban provinces than rural ones ${ }^{3}$ die from interpersonal violence. Literature suggests other determinants implicated in homicidal victimization include alcohol and drug use, temporality, seasonality and location (Seedat et al. 2009; Ratele \& Suffla 2010).

The question becomes, what makes young Black males vulnerable to violent death and in what way is masculinity implicated? Given the overrepresentation of males in homicidal violence, the determinants highlighted in the literature are possibly tied to constructions of masculinity and men's struggles with power as well as perceived threat to their gender power. Even then, there is a need for additional explanations because of the preponderance of Black male victims.

\section{Hegemonic Masculinity, Subordinate Men, and Violence}

10 Black young men are rendered vulnerable to homicidal victimization not by a single factor such as availability of firearms or alcohol. Rather homicide is determined by a range of often inseparable dynamics located at individual, relationship, community and societal levels (Rosenberg et al. 2006). Among several posited explanations for the disproportionate representation of young Black men in homicide include: subscription to dominant, patriarchal, traditional, ruling or hegemonic masculinity; a past marked 
by apartheid racism and segregation, state repression, arbitrary detentions, political unrest and violence, and a struggle for national liberation; rapid urbanisation; high levels of unemployment; racially inflected socio-economic inequality and poverty in democratic post-apartheid society; substance and alcohol abuse; a violence-rich subculture; and the weaknesses of the criminal-justice system (Breckenridge 1998; Segal et al. 1999; Schönteich \& Louw 2001; Parker et al. 2004; Seedat et al. 2009; SAPS 2011). The latter explanation, with its inclination towards militarisation and a discourse of "toughness", has tended to dominate how violence is apprehended as well as state responses and popular reactions regarding the control and reduction of homicides. The tendency to call for increased number of police, stiffer sentences for perpetrators, and building more prisons obtains in the case of South Africa as in many other countries troubled by high rates of violence. Yet the array of explanations and interest in understanding violence in its various forms, by scholars in a range of disciplines, cues the fact that the problematic crosses disciplinary boundaries and may require complex responses. Violence demands to be accounted for at structural, symbolic and subjective levels. Also, there is need for explanations that focus more clearly on vulnerability of Black young males to deadly violence as a separate question from violence perpetration. And in a country with a unique history of a legalised repressive race, gender and sexual regime like South Africa, the levels and intractability of interpersonal violence suggest a need to examine not only the workings of the criminal-justice system, but also the possible consequences of that very history on victimization.

11 The diversity of explanations and complexity of homicide notwithstanding, a concept that has received widespread use within studies on men's violence against other men and women by critical students of masculinity is hegemonic masculinity under its various guises (Carrigan et al. 1985; Morrell 1998; Connell \& Messerschmidt 2005; Ratele 2008). In their initial formulation the Australian scholars Carrigan et al. (1985: 592) stated that "the ability to impose a particular definition on other kinds of masculinity is part of what we mean by "hegemony". The concept was employed to refer to "how particular groups of men inhabit positions of power and wealth, and how they legitimate and reproduce the social relationships that generate their dominance. An immediate consequence of this is that the culturally exalted form of masculinity, the hegemonic model so to speak, may only correspond to the actual characters of a small number of men [...]. Yet very large numbers of men are complicit in sustaining the hegemonic model" (ibid.: 592). The authors cautioned against seeing hegemonic masculinity as another way of speaking about the male role. Instead, it refers to "a particular variety of masculinity to which others-among them young and effeminate as well as homosexual men-are subordinated" (ibid.: 587).

While there is evidence of essentialization and universalization of hegemonic masculinity in the literature, many scholars apprehend the concept as a shifting pattern of things men do as men that grants men dominance over women and some men over other men. Hegemonic masculinity is thus distinguished from other marginalized or subordinate masculinities in terms of cultural currency. As a ruling form of being a man or boy on a schoolyard, neighbourhood, workplace, or larger society, the culturally exalted masculinity will tend to silence, marginalize and oppress other ways of being a man or boy. Gay masculinities are a visible variety of ostracized and subjugated manhoods which, with reference to Africa in the last number of years, 
have particularly troubled hetero-patriarchal politics (Epprecht 2008; Usiwa-Usiwa 2010). As such, while masculinities are tied together by the fact of domination over women, the concept of hegemony within men alerts us to crucial differences between masculinities that need to be recognized. The concept presents a view of a world characterized by different masculinities in on-going contestation and struggle. In Segal's (1993: 635) terms, a form of masculinity "gains its symbolic force and familiar status [...] from a series of hierarchical relations to what it can subordinate". South African historian and masculinity scholar Robert Morrell (1998: 608) contended that "in addition to oppressing women, hegemonic masculinity silences or subordinates other masculinities, positioning these in relation to itself such that the values expressed by these other masculinities are not those that have currency or legitimacy. In turn, it presents its own version of masculinity, of how men should behave and how putative 'real men' do behave, as the cultural ideal. The concept of hegemonic masculinity provides a way of explaining that though a number of masculinities coexist, a particular version of masculinity holds sway, bestowing power and privilege on men who espouse it and claim it as their own".

13 I shall propose that, the utility of the concept notwithstanding, to use hegemonic masculinity tout court in trying to understand Black masculinities is not always useful. As subordinate masculinities within the context of hegemonic capitalist patriarchal whiteness, Black masculinities are a set of dominated configurations and positionings. Needless to say, though often racially and economically subordinated some Black men are complicit with hegemonic masculinity.

14 While there have been critiques (Donaldson 1993), the concept hegemonic masculinity and its implications has been highly influential in talking of men, including among South African researchers. For instance, Morrell (1998: 607-608) supports the conceptualization in stating that hegemonic masculinity is "the form of masculinity which is dominant in society. This is not a question of head-counts, but a 'question of relations of cultural domination"'. Vincent (2006: 355) states that "hegemonic masculinity signals the fact that at any given social moment, some men are in a position to impose their particular definitions of masculinity on others in order to legitimate and reproduce the social relations that generate their dominance. The concept also provides the important insight that although large numbers of men benefit from an unequal gender order, they do not benefit equally". And Walker (2005: 233) reported that the men she studied perceived "the costs of hegemonic masculinity [...] (to) outweighed the benefits".

In addition to the existence of a variety of masculinities, the most germane conclusion from this conceptualization and subsequent studies on men and masculinity is perhaps that regarding intra-male group power: the domination of a group of men over other men (and not only women), the relationship of hegemonic to other forms of being a man. Black young men seem to fulfill an important criterion of subordinate masculinities: generally they do not have social power and wealth. As Donaldson (1993: 645-646) remarked, "although cross-class, (hegemonic masculinity) often excludes working-class and black men". This exclusion, while denying successful manhood to these subjects, opens an avenue for the creation of a variety of hegemonic masculinities within subordination. This is an arena where, within historically powerless race groups or subordinate classes, some masculinities are simultaneously hegemonic and 
subordinate. Where masculinities are seen as in constant contest, Black young men victimise each other from a location of powerlessness.

Connell and colleagues (2005: 587) remarked the subordination of homosexuality and youth. However, there is a need to accentuate that masculinity conceived of "as a structure of social relations" allows for an account of domination on the basis of other exclusionary structures. In many cases, within the symbolic structure of capitalist, patriarchal whiteness, Black young men are marginalized also because of, amongst others, skin colour, little or no income, level of education, nationality, and language. Gender is not the only factor constitutive of the form that (subordinate young Black) manhood assumes.

The understanding that gender, income, sexuality and race are co-constitutive of men's practices has inspired the now well-accepted idea in critical masculinity studies that, as Morrell (1998: 607) averred, "in any society there are many masculinities, each with a characteristic shape and set of features. The contours of these masculinities change over time, being affected by changes elsewhere in society and at the same time, themselves affecting society itself. It is not the case that all masculinities are equally powerful as social forces. Subordinate and subversive masculinities exist among marginal or dominated groups and these may be oppositional to the dominant masculinity". Within a race, too, there is not one single form of masculinities. Among Blacks, then, different masculinities with unequal social value exist. Young men of the race, not unlike homosexual black men, are often structurally and symbolically silenced. In some communities (such as among the Xhosa), this silence of most but the old and initiated is encoded into tradition and culture. In urban settings too, the dividends of patriarchy are actually paltry for Black young men, more so if they are also unemployed, poor, poorly uneducated, and not heterosexual. Contrary to Morrell's cautionary note, it is no exaggeration to submit that the intersection of inequality, poverty, race, youth and gender might in fact endangers Black young men's lives. Whatever bodily and institutional powers their support of hegemonic masculinity affords in their families and neighborhoods, the distribution and pattern of homicide in South Africa indicates that this group is at highest risk of homicidal victimization because of their equivocal positioning within the patriarchal system.

The existence of subordinate masculinities in their relation to powerful men obliges us to see the construction of masculinity "as a social struggle going on in a complex ideological and political field, in which there is a continuing process of mobilization, marginalization, contestation, resistance, and subordination" (Carrigan et al. 1985: 589). Black young men, that is, whether politically and socially conscious or not, must be understood as engaged in a struggle against their subordination, as far as their gender lives are concerned. In their article in which they revisit the concept Connell and Messerschmidt (2005: 832) state: "Hegemonic masculinity was understood as the pattern of practice (i.e., things done, not just a set of role expectations or an identity) that allowed men's dominance over women to continue. Hegemonic masculinity was distinguished from other masculinities, especially subordinated masculinities. Hegemonic masculinity was not assumed to be normal in the statistical sense; only a minority of men might enact it. But it was certainly normative. It embodied the currently most honored way of being a man, it required all other men to position themselves in relation to it, and it ideologically legitimated the global subordination of women to men." They also note that "the concepts of hegemonic and subordinated 
masculinities helped in understanding not only men's exposure to risk but also men's difficulties in responding to disability and injury" (ibid.: 834).

According to Breckenridge (1998: 674), violence in the South African mines was central to masculine self-definition in men's conflict on the mines where aggression "formed part of a very complex field of cultural practice". Others have supported the claim that men's violence is integral to constructions and expressions of dominant masculinities (Boonzaier \& De La Rey 2003; Jewkes et al. 2006; Stevens 2008). Even though hegemony does not imply violence, the domination of some men over others is often forcefully achieved. Engaging violently with other men and risking death might apply especially in the case of young Black men who have comparably decreased opportunities to demonstrate socially exalted forms of manhood (Barker \& Ricardo 2005: 8).

Now, while the association between violence and hegemonic masculinity is wellrecognised in critical studies on men and masculinities, the link between men's elevated risk for lethal violence victimization and masculinity-related fear has not received the examination it deserves. I turn and contend that some expressions of violence are not simplistically and always about dominating other men. Men's violence is at times a response to others' violence, including violence from the state and other structures in society. At other times violence works to deflect internal states of vulnerability, a way to deal with feelings of fear and insecurity. The use of violence against others' violence and to deflect internal states of vulnerability is not necessarily unconnected to masculinity constructions. Regardless of what motivates violence, in certain instances these violent behaviours arising from fear and insecurity might put a man at risk of violent death. While aggressing against women or children at home may pose less of a risk, but not zero risk, for a man, aggression against other men apparently poses increased risk to fatal bodily harm to oneself and others. In a situation where another man is willing to escalate things to prove his manhood through violence too, the ensuing argument can result in injury or death of one of the protagonists. The police have indicated that indeed over half of "social fabric-related murders (and attempted murders) result from arguments which subsequently deteriorate into fights" (SAPS 2009: 9). Similar findings have been reported for the United States where most murders result from aggravated disputes (O'Flaherty \& Sethi 2010).

\section{Tracing Emotions: Fear and Fearlessness in Black Young Men's Vulnerability to Homicide}

21 Young African men's vulnerability to homicide arises from a complex interaction of historically inscribed subjective, emotional states and objective, economic and sociopolitical conditions. This vulnerability does not uniformly apply to all young Black men given the heterogeneity of the group and subjective differences that have to be kept in mind. And as noted earlier, there are other multiple influences and complex dynamics at play associated with men's homicide risk. A critical approach against essentializing masculinity requires recognition of the significance of situating individual men's behaviour in its context that contours what subjects do in relation to others and the external world, including what they do that makes them vulnerable to early death. Arguably, this is particularly important in context of historical colonial and apartheid. Such an approach allows for the demonstration of how understandings of particular 
behaviours, such as homicide, become framed by social, political and economic processes (Laubscher 2005).

The social-emotional complex that generates vulnerability to homicide is possibly tied to the country's history. Contemporary societal socio-economic dynamics in which large numbers of young Black males are unemployed and not in education settings play a part also. Particularly significant in this social-emotional complex is the interaction of fear and fearlessness (which should be seen as part of a broader spectrum of negative affect) as an often overlooked consideration in thinking of young African men's lives. To this end, it has been argued that "it is specifically those practices that some men engage [...] to express their manhood and demonstrate fearlessness that heighten vulnerability to, or perpetration of, violence" (Ratele 2010: 21).

Courage, guts, or fearlessness is a common and compelling stereotype definitive of dominant masculinity in South Africa and other parts of the world connected to masculinity. Ratele (ibid.) argues that under pressure to never reveal fear and anxiety and thus present as man enough motivates many a young male to actively support the idea that masculinity means playing it cool, ignoring pain, and never walking away from a fight. For young Black men in particular successful masculinity might come to represent a "no-fear" pose (ibid. 2008). To say "young Black men in particular" is to highlight the fact that in comparison to White men, South African Black young men as a group have relatively limited opportunities to achieve the societally exalted masculinity and the body offers one of the few opportunities to express masculine dominance. Support for the idea of fearless masculinity might be render large numbers of young black males vulnerable to homicide because bodily expressions of fearlessness include following through on the show of heroism by inflicting violence on others or withstanding it.

The association between Black young men's vulnerability for homicide and their unspoken fear is hidden under a façade of "no fear" bravado, remainings largely unrecognised. Black young men's fear is unspoken because they are often represented as the objects of fear. In the context of the US, Ladson Billings (2011: 10) has observed that "there exists a widespread fear of (young Black males) throughout the society". However, Black men in South Africa, and possibly the US, have much to fear from society, starting with fearing state violence to fearing the violence of other men.

While not always articulated, the fear that characterises Black men and is formative of Black masculinity is generalised and specific. The former entails anxiety and sense of economic and psychosocial insecurity in the face of negative treatment by society, including the likelihood to be unemployed, arrested, and harsher sentences. Ladsons Billings (ibid.: 9) also stated that "for example, I cannot think of very many young Black men who have not had the experience of having some woman-of any race-cross the street to avoid contact with them. This behavior coupled with things like women clutching their purses, people stepping out of elevators when Black males step in, or having taxi drivers routinely pass Black male passengers on the street are a part of daily experiences of Black men in this society".

The latter form of fear arises from immediate conditions as when confronted by another man. This form of fear is formative of the dominant form of manhood in many cultures. Although writing about US masculinity, Michael Kimmel's (1994: 131) observation applies to South Africa: "The fear of being seen as a sissy dominates the cultural definitions of manhood. It starts so early. [...] I have a standing bet with a 
friend that I can walk onto any playground in America where 6-year-old boys are happily playing and by asking one question, I can provoke a fight. That question is simple: 'Who's a sissy around here?' Once posed, the challenge is made. One of two things is likely to happen. One boy will accuse another of being a sissy, to which that boy will respond that he is not a sissy, that the first boy is. They may have to fight it out to see who's lying. Or a whole group of boys will surround one boy and all shout 'He is! He is!' That boy will either burst into tears and run home crying, disgraced, or he will have to take on several boys at once, to prove that he's not a sissy. (And what will his father or older brothers tell him if he chooses to run home crying?) It will be same time before he regains any sense of self-respect" (ibid.: 131-132). Kimmel was suggesting that violence can be a defense against being exposed as not a real man, a fear that infects even boys. Where a group of men were denied their manhood by being denied any right except those that serve to uphold patriarchal capitalist White supremacy, the sense of insecurity that they are not real men is not baseless. It is a fear that is (also) intergenerationally transmitted. The young Black man's fear that that he might not be as manly as he pretends to be is not without foundation: it comes from seeing his grandfathers and father reduced to "boys" by violent, capitalist, racist, patriarchy. $\mathrm{He}$ might have hoped that he will have more power than his forbearers, but because of his status and voicelessness, he is (already) a failure in the eyes of other men.

Fearlessness may also be a response to perceived danger of expressing fear in violent neighborhoods. Young men adopt an attitude of fearlessness and suppress fear as "inappropriate" because fear can be seen as a sign of weakness that may lead to greater risk of victimisation (Brownlow 2005). O'Flaherty and Sethi (2010) have contended that "murder can be a preemptive act driven by the fear of being killed". Carrying a weapon when going out at night is an indication that young men do experience fear, though they may not readily admit it. Unfortunately, the suppression of functional fear and adoption of a posture of fearlessness puts at them at increased of deadly violence or killing others. Fear and fearlessness have thus to be seen as connected integral elements of the emotion spectrum that mark young African men's lives, which also go into the construction of masculinity.

Researchers have long debated the causative importance of emotions such as frustration and anger in violent behaviour (Berkowitz 1989; Smith \& Furlong 1998). In his support of the validity of the original frustration-aggression hypothesis, Berkowitz's (1989: 71) reformulation states that "frustrations generate aggressive inclinations only to the extent that they produce negative affect". This line of research is not well-developed in research on men and masculinities in South Africa. However, a qualitative study by Clowes and her colleagues (2010) pointed to feelings of frustration, sense of inadequacy, shame, humiliation and perceptions of disrespect as risk factors to male interpersonal violence. In the study participants stated that some men employ violence to instill fear in others in order to get respect. But participants also said that it is when men are frustrated for "having nothing", don't feel good, or experience feelings of gendered inadequacy about themselves that they try to aggressively regain control. Fear or feelings of inadequacy may arise from an apparently innocuous namecalling, being called soft or afraid. In order to stave off the feelings of inadequacy, where the labels are interpreted as indicative of masculine lack, some young men use violence to feel good, get back respect, regain control and ultimately prove their 
manhood. Even then, what demands underscoring is the connection of this web of emotions to young men's vulnerability to early death from interpersonal violence.

While not on homicide victimization per se, Bruce (2006: 34) has offered an interpretation of the role of some of these emotions in violence in South Africa. His argument centered on the relation of self-esteem and racism to violence, and argued that "the roots of violence are often found in mental-emotional states which serve as a psychological defense or compensation for low self-esteem. Perhaps the most important of these for understanding why people react very aggressively to minor insults (whether real or perceived), is a state of mind, underpinned by low self-esteem, which is associated with an inflated idea of one's own worth or status". He connects subjective states with material conditions. He asserted that we should see interpersonal violence as tied to status-related psychological insecurity which in turn is magnified by high levels of inequality. "Heightened levels of inequality may feed feelings of inferiority and insecurity among people relating to their status. [...] In so far as they increase insecurity about status, social and economic factors increase the psychological motivation to compensate for this inferiority through inflated ideas about one's own worth. This in turn may increase the disposition to feel threatened by minor acts which are interpreted as challenging one's status" (ibid.: 34). But a young Black man is more likely to only respond to someone equally or even more powerless. It is when another man or woman perceived to have equal or lower status has overstepped the mark that it the response can becomes violent. "The combination of low self-esteem and an inflated concept of one's worth are the volatile mix that leads to certain forms of aggression" (ibid.: 35). Bruce said that "feelings of insecurity on the part of men who are invested in ideas about male superiority [...] could contribute to gender [...] violence as well as aggression against other men from their own social group" (ibid.).

30 A number of crucial omissions and problems are apparent in this analysis. One is the neglect of young Black males' vulnerability to violence. Another is the implicit blaming of young Black men for their low self-esteem and feelings of insecurity. A third is the lack of attention to the history of fear in the political and social South Africa.

31 Fear shapes masculinity. In turn masculinity norms and structures in society constrain or facilitate how men react to their own fears. Furthermore, in order to fully appreciate the role and interaction of fear and fearlessness in young South African masculinities and violence victimization and perpetration it is important to understand the history of the racial and gender aspects of emotions in the country. Black men's fear and demand to be heroic is rooted in history.

\section{The Roots of Young Black Men's Fear and Its Neglect}

Researchers have recognised that South Africa's history of conflict, economic inequalities and forced removals, resulting in disrupted families, migrancy, and torn communities have shaped contemporary forms of masculinity (Moodie \& Ndatshe 1994; Coovadia et al. 2009). However, the constitutive role of emotions in the make-up of South Africa itself and masculinities is not as well-recognised. Emotions are an essential element in the judgments and decisions people make in daily life (Finucane et al. 2000). They are at the root of all aggressive behavior and violence. And negative emotions such as dysfunctional fear, anger, and shame are the key link between experiencing unfavorable events and the shape that violent masculinities assume 
(especially where there is inadequate social support from others). Inability to deal with fear, anger, shame and other negative emotions are is possibly the proximate factors that makes young men vulnerable to fatal interpersonal violence (Maschi et al. 2008). Because traumatic events can be overpowering, young men who grow up confronted with continuous traumatic events, can have the normal development of emotional regulation skills hindered. Such continuous obstacles are bound to be overwhelming and most likely preclude trial-and-error emotional regulation skills development that exists in warm mutually supportive families in less violent neighborhoods (Briere 2002). Young men who do not have adequate emotional skills in violent neighborhoods may be more vulnerable to non-lethal violence victimization and homicide.

The role of emotions in the make-up of apartheid South Africa and Black manhood was recognised by Steve Biko, the black consciousness movement leader who was killed by apartheid police while in detention. Specifically in his seminal essay on fear written in 1971 ("Fear-an important determinant in South African politics"), but also in his other published writings and interviews, Biko (2004) was keenly observant of the sociopolitical significance of emotions. Fear was the principal emotion Biko saw as characteristic of apartheid South Africa. His argument on the role of emotions is easily extended to the vulnerability of young Black men to homicidal violence in contemporary society.

In his editor's note prefacing the essay on fear, Aelred Stubbs, the editor of Biko's wellknown volume of selected writings, I write what I like, notes that at the time Biko wrote the piece, "the theory of Black Consciousness was still very much being filled out through discussion and writing [...]. In this piece Steve was making the point that ever since the white man arrived as a settler in Southern Africa he had created and then preserved for himself a special position of privilege. This position was created and preserved by the use of violence and fear, but the use of these methods was in itself a result of the white man's fear of the black population"4. Out of this we understand that fear pervaded Southern Africa. It had deep colonial roots. It was connected to process of privileging masculine whiteness. To maintain white privilege, violence became imperative. Thus, racialised fear, white male privilege, the subjugation of blacks, and violence are interconnected.

In an interview published in The New Republic in January 1978, Biko (2004: 175) declared that "you are either alive and proud or you are dead, and when you are dead, you can't care anyway. And your method of death can itself be a politicising thing. So you die in the riots. For a hell of a lot of them, in fact there's really nothing to lose-almost literally, given the kind of situations that they come from". By them Biko was referring to young Black men, although he does not spell this out. By the kind of situations that they come from he was talking about the structural wretchedness of black lives. While we may differ with Biko's thought that to live with fear and no pride-reading pride to mean dignity, self-esteem and a sense one's worth, rather conceit or self-importanceis no better than to be dead, I propose that ignoring the destructive effects of fear, and more generally of unpleasant affect, is one of the obstacles in the way of bringing down levels of violence in South Africa and transforming African masculinities.

According to Biko (ibid.), the apartheid government and security forces were ruled by fear, in spite of their immense violent racist patriarchal power. Biko was concerned with the "deeply imbedded fear of the Black man [...] prevalent in white society" (ibid.: 85) as much as Black men's fear of Whites. Through the actions of the police, army, 
security agents, trigger-happy white farmers and store owners, Biko contended, apartheid successfully instilled fear in Black men to the point where these men could not "insist on the observance of their manhood" (ibid.: 83). Biko's argument suggested that the apparent fear-inducing capacity of the Black man's body was to be understood as intertwined with Black men's fear of white society, a dynamic that possibly persists into the present. The stylised appearance of Black masculinist invulnerability is thus a compensation for pervasive insecurity in their lives, an insecurity which is both psychological and material.

Another set of emotions Biko observed as playing a large part in South Africa was anger, rage and hatred. He saw a connection between anger, rage, hatred and fear. His contention was that the fear observable among the oppressed "hides underneath it an immeasurable rage that often threatens to erupt" (ibid.: 84). Biko pointed to racist cruelty as the source which led to "a situation of absolute want in which Black will kill Black to survive" (ibid.: 82). Thus emotions, alongside the creation of scarcity, are of importance to rulers because they form some the most effective tactics which any oppressor cannot do without: to win the hearts (and minds) of the oppressed, to turn them against themselves and each other. Young African men's powerlessness and performances of fearlessness are thus densely entwined. Their violence against others is interlaced with insidious but rarely admitted generalised and specific fear. According bell hooks, "when feminist women insist that all men are powerful oppressors who victimize from the location of power, they obscure the reality that many victimize from the location of victimization. The violence they do to others is usually a mirroring of the violence upon and within the self. Failure to examine the victimization of men keeps us from understanding maleness, from uncovering the space of connection that might lead more men to seek feminist transformation" (ibid.: 139-140).

Five years after Biko wrote his ideas, the raging emotions exploded, as it were. South Africa was wracked by student uprising. Arguably, the uprising was led mostly by Black young male high school students. The uprising was met by violent repression from the State. Many young men left the country to get military training. Many others remained and became part of the struggle to make the country ungovernable ${ }^{5}$. The militancy of the youth and their struggle against apartheid patriarchy and racism was to contribute to the further destabilisation of their families, communities and their own personal lives. Although apartheid policies were part of the forces responsible for Black family destabilisation, the militancy and central role of Black youth in struggles from the 1970s radically also altered family relationship and affective ties were, rupturing interpersonal emotional bonds and disrupting existing cultural norms. For some men and their families, and the generations of boys and men that followed them, those affective bonds might be in need of repair still (Statistics South Africa 2010; Holborn \& Eddy 2011), and possibly are involved in the high number of Black young men who are vulnerable to violence victimization in post-apartheid South Africa.

In this paper I argued for a closer look at Black young men's vulnerability for violent death in relationship to hegemonic and subordinated masculinity. As a background I presented the statistics indicating that young Black South African men are the most likely homicide victims in order to locate the question why risk for early death from interpersonal violence continue to be high amongst this group. My main contention in the paper is that while Connell and associates' influential concept of hegemonic 
masculinity might be useful, paying attention to the life of emotions of young Black men, in relation to race histories, offers insight on the ambiguous and tenuous positioning of subordinated masculinities on the terrain of violence and gender. The ambiguous positioning of African young men within the labyrinthine violent, capitalist, racist, patriarchal, homophobic structure (in which they are convinced to, on the one hand, support the dominant ideologies constitutive of Black masculinity and, on the other hand, likely to be die from violence which ultimately upholds that the complex), is seen as calling for more closely examined studies and better explanations. The paper argued for taking more seriously the fact that while usually perceived to support to hegemonic masculinity, young Black men are subordinated to precisely this form of masculinity.

41 I thus turned to look at the possible role of emotions in young African men's violence victimization and the performance of hegemonic masculinity as subordinate subjects. I traced the history of fear, insecurity and anger as observed by the Black consciousness leader Steve Biko, in the making of history and politics of South Africa. I sought to make more salient the role of fear, especially in relation to a façade of fearlessness, in the construction of subordinated yet prevalent form of young Black masculinity. I underlined what I see as the crucial role of emotions in seeking to understand Black men's likelihood vulnerability to fatal violence. Therefore, in closing, I wish to underline the importance of thickly described critical studies of the as yet underexamined Black South African men's emotional lives in projects on violence generally and homicide more specifically.

\section{BIBLIOGRAPHY}

BARKER, G. \& RICARDO, C.

2005 - Young Men and the Construction of Masculinity in Sub-Saharan Africa: Implications for HIV/Aids, Conflict, and Violence, Paper No. 26 (Washington D.C. Conflict Prevention \& Reconstruction Social Development Department, The World Bank).

BERKOWITZ, L.

1989 - "Frustration-Aggression Hypothesis: Examination and Reformulation", Psychological

Bulletin 106: 59-73.

BIKO, S.

2004 - I Write What I Like (Johannesburg: Picador Africa).

BOONZAIER, F. \& DE LA REY, C.

2003 - “'He's a Man, and I'm a Woman': Cultural Constructions of Masculinity and Femininity in South African Women's Narratives of Violence”, Violence Against Women 9: 1003-1029.

BRADSHAW, D., GROENWALD, P., LAUBSCHER, R. ET AL.

2003 - Initial Estimates from the South African National Burden of Disease Study (Tygerberg: Medical Research Council). 
BRECKENRIDGE, $\mathrm{K}$.

1998 - "The Allure of Violence: Men, Race and Masculinity on the South African Goldmines, 1900-1950", Journal of Southern African Studies 24 (4): 669-693.

BRIERE, J.

2002 - "Treating Adult Survivors of Severe Childhood Abuse and Neglect: Further Development of an Integrative Model", in J. E. B. MYERS, L. BERLINER et al. (eds.), The APSAC Handbook on Child Maltreatment (Newbury Park, CA: Sage): 175-202.

BROWNLOW, A.

2005 - “A Geography of Men's Fear”, Geoforum 36: 581-592.

BRUCE, D.

2006 - "Racism, Self-Esteem and Violence in SA: Gaps in The NCPS' Explanation?", SA Crime Quarterly 17: 13-20.

CARRIGAN, T., CONNELL, R. W. \& LEE, J.

1985 - "Toward a New Sociology of Masculinity", Theory and Society 14 (5): 551-604.

CLOWES, L., LAZARUS, S. \& RATELE, K.

2010 - "Risk and Protective Factors to Male Interpersonal Violence: Views of Some Male University Students", African Safety Promotion: A Journal of Injury and Violence Prevention 8 (1): 1-19. CONNELL, R. W. \& MESSERSCHMIDT, M.

2005 - "Hegemonic Masculinity: Rethinking the Concept", Gender Society 19: 829-895.

COOVADIA, H., JEWKES, R., BARRON, P. ET AL.

2009 - "The Health and Health System of South Africa: Historical Roots of Current Public Health Challenges", The Lancet, <http://www.doi:10.1016/S0140-6736(09)60951-X>.

COVINGTON, J.

2003 - "The Violent Black Male: Conceptions of Race in Criminological Theories", in D. F. HAWKINS (ed.), Violent Crime: Assessing Race and Ethnic Differences (Cambridge: Cambridge University Press): 254-279.

DONALDSON, M.

1993 - “What Is Hegemonic Masculinity?", Theory and Society 22 (5): 643-657.

DONSON, $\mathrm{H}$.

2009 - A Profile of Fatal Injuries in South Africa: Annual Report of the National Injury Mortality Surveillance System (Tygerberg: Medical Research Council).

DOOLAN, K., EHRLICH, R. \& MYER, L.

2007 - "Experience of Violence and Socioeconomic Position in South Africa: A National Study", PLoS ONE 12: 1-6, <http://www.e1290.doi:10.1371/journal.pone.0001290>.

DUNKLE, D. L., JEWKES, R. K., BROWN, H. C. ET AL.

2004 - "Gender-Based Violence, Relationship Power, and Risk of HIV Infection in Women Attending Antenatal Clinics in South Africa", Lancet 363: 1415-1421.

EPPRECHT, M.

2008 - Heterosexual Africa? The History of an Idea from the Age of Exploration to the Age of AIDS (Athens: Ohio University Press; Scottsville: University of Kwazulu Natal Press).

FINUCANE, M. L., ALHAKAMI, A., SLOVIC, P. \& JOHSON, S. M.

2000 - "The Affect Heuristic in Judgments of Risks and Benefits", Journal of Behavioural Decision Making 13 (1): 1-17. 
GROENEWALD, P., BRADSHAW, D., DANIELS, J. ET AL.

2008 - Cause of Death and Premature Mortality in Cape Town, 2001-2006 (Cape Town: South African Medical Research Council).

HAWKINS, D. F.

2003 - Violent Crime: Assessing Race and Ethnic Differences (Cambridge: Cambridge University Press).

HOLBORN, L. \& EDDY, G.

2011 - First Steps to Healing the South African Family (Johannesburg: South African Institute of Race Relations).

JEWKES, R., DUNKLE, K., KOSS, M. P. ET AL.

2006 - "Rape Perpetration by Young, Rural South African Men: Prevalence, Patterns and Risk

Factors", Social Science and Medicine 63: 2949-2961.

KIMMEL, M. S.

1994 - "Masculinity as Homophobia: Fear, Shame, and Silence in the Construction of Gender Identity", in H. BROD \& M. KAUFMAN (eds.), Theorizing Masculinities (Thousand Oaks, California: Sage): $119-141$

KRUG, E. G., DAHLBERG, L. L., MERCY, J. A., ET AL.

2002 - World Report on Violence and Health (Geneva: World Health Organization).

LADSON BILLINGS, G.

2011 - “Boyz to Men? Teaching to Restore Black Boys' Childhood”, Race Ethnicity and Education 14 (1): 7-15.

LAUBSCHER, L.

2005 - “Toward a (De)constructive Psychology of African American Men”, Journal of Black

Psychology 31 (2): 111-129.

LOPES, P. N., SALOVEY, P., CÔTE, S. \& BEER, M.

2005 - "Emotion Regulation Abilities and the Quality of Social Interaction", Emotion 5 (1): 113-118.

MAMAN, S., CAMPBELl, J., SWEAT, M. D. \& GIELEN, A. C.

2000 - "The Intersections of HIV and Violence: Directions for Future Research and

Interventions", Social Science \& Medicine 50: 459-478.

MASCHI, T., BRADLEY, C. A. \& MORGEN, K.

2008 - "Unraveling the Link Between Trauma and Delinquency: the Mediating Role of Negative

Affect and Delinquent Peer Exposure", Youth Violence and Juvenile Justice 6: 136-157.

MATZOPOULOS, R., MEYERS, J. E., BOWMAN, B. \& MATHEWS, S.

2008 - "Interpersonal Violence Prevention: Prioritising Interventions", South African Medical Journal 98 (9): 682-690.

MOLLER, V.

1998 - “Quality of Life in South Africa: Post-apartheid Trends”, Social Indicators Research 43: 27-68.

MOODIE, T. D. \& NDATSHE, V.

1994 - Going for Gold: Men, Mines and Migration (Berkeley: University of California Press).

MORRELL, R.

1998 - "Of Boys and Men: Masculinity and Gender in Southern African Studies", Journal of

Southern African Studies, Special Issue, Masculinities in Southern Africa 24 (4): 605-630. 
NORMAN, R., MATZOPOULOS, R., GROENEWALD, P. \& BRADSHAW, D.

2007 - "The High Burden of Injuries in South Africa", Bulletin of the World Health Organisation 85

(9): 695-702.

O'FLAHERTY, B. \& SETHI, R.

2010 - "Homicide in Black and White", Journal of Urban Economics, <http://www.doi:10.1016/j.jue.

2010.06.001>.

OLIVER, W.

2003 - "The Structural-Cultural Perspective: A Theory of Black Male Violence", in D. F. HAwKINS

(ed.), Violent Crime: Assessing Race and Ethnic Differences (Cambridge: Cambridge University Press): 280-302.

PARKER, Z., DAWES, A. \& FARR, V.

2004 - "Interpersonal Youth Violence Prevention", in S. sUfLLA \& A. VAN NIEKERK (eds.), Crime, Violence and Injury Prevention in South Africa: Developments and Challenges (Tygerberg: Medical Research Council-University of South Africa Crime, Violence and Injury Lead Programme): 22-39. POWDTHAVEE, N.

2005 - "Unhappiness and Crime: Evidence from South Africa", Economica 72: 531-547.

RATELE, $\mathrm{K}$.

2008 - "Masculinity and Male Mortality in South Africa", African Safety Promotion: A Journal of Injury and Violence Prevention 6 (2): 22-35.

2010 - "Watch Your Man: Young Black Males at Risk of Homicidal Violence", SA Crime Quarterly

33: $19-24$.

RATELE, K., SMITH, M., VAN NIEKERK, A. \& SEEDAT, M.

2011a - "Is it Race, Age or Sex? Masculinity in Male Homicide Victimisation in Urban South Africa", in C. GOULD (ed.), National and International Perspectives on Crime and Policing (Pretoria: Institute for Security Studies): 44-58.

RATELE, K. \& SUFFLA, S.

2010 - "Men, Masculinity and Cultures of Violence and Peace in South Africa", in C. BLAzINA \& D. S. SHEN-MILLER (eds.), An International Psychology of Men: Theoretical Advances, Case studies, and Clinical Innovations (New York: Routledge): 27-55.

2011 - "Violence, Masculinity and Well-being", in K. KONDLO \& C. EJIOGU (eds.), Africa in Focus: Governance in the $21^{\text {st }}$ Century (Cape Town: HSRC Press): 259-281.

ROSENBERG, M. L., BUTCHART, A., MERCY, J. ET AL.

2006 - "Interpersonal Violence", in D. T. JAMISON, J. G. BREMAN et al. (eds.), Disease Control Priorities in Developing Countries (New York: Oxford University Press): 755-770.

SCHÖNTEICH, M. \& LOUW, A.

2001 - Crime in South Africa: A Country and Cities Profile, Institute for Security Studies, Occasional Paper No. 49, <http://www.issafrica.org/Papers/49/Paper49.html>.

SEEDAT, M., JEWKES, R., VAN NIEKERK, A., SUFFLA, S. \& RATELE, K.

2009 - "Violence and Injuries in South Africa: Prioritising an Agenda for Prevention", Lancet 374

(9694): 1011-1022.

SEGAL, L.

1993 - "Changing Men: Masculinities in Context", Theory and Society, Special Issue, Masculinities 22 (5): 625-641. 
SEGAL, L., PELO, J. \& RAMPA, P.

1999 - ““Asicamtheni Magents': Let's Talk, Magents”, Crime and Conflict 15: 23-27.

SMITH, D. C. \& FURLONG, M. J.

1998 - "Introduction to the Special Issue: Addressing Youth Anger and Aggression in School

Settings", Psychology in the Schools 35 (3): 201-203.

SOUTH AFRICAN POLICE SERVICE (SAPS).

2009 - Annual Report: 1 April 2008 to 31 March 2009 (The Crime Situation in South Africa), <http://

www.saps.gov.za/saps_profile/strategic_framework/annual_report/

2008_2009/2_crime_situation_sa.pdf>.

2010 - Annual Report: 1 April 2009 to 31 March 2010 (The Crime Situation in South Africa), <http://

www.saps.gov.za/saps_profile/strategic_framework/annual_report/

2009_2010/2_crime_situation.pdf>.

2011 - Annual Report: 1 April 2010 to 31 March 2011 (Annexure A: The Crime Challenge Facing the South

African Police Service), <http://www.saps.gov.za/saps_profile/strategic_framework/

annual_report/2010_2011/10_crime_challenge_saps.pdf>.

2012 - An Analysis of the National Crime Statistics: Addendum to the Annual Report 2011/2012. Annual

Report (Pretoria: SAPS Corporate Communications).

STATISTICS SOUTH AFRICA

2010 - Social Profile of South Africa, 2002-2009 (Pretoria: Statistics South Africa).

STEVENS, G. R.

2008 - Men and Meanings of Murder: Discourses of Power in the Narratives of Male Homicide in South Africa (Pretoria: University of South Africa).

UNION OF SOUTH AFRICA

1950 - Population Registration Act (No. 30 of 1950) (Statutes of the Union of South Africa) (Pretoria:

Republic of South Africa).

UNITED NATIONS OFFICE ON DRUGS AND CRIME (UNODC)

2011 - Global Study on Homicide: Trends, Contexts, Data (Geneva: United Nations Office on Drugs and Crime).

USIWA-USIWA, N.

2010 - "In the Chief Resident Magistrate's Court, Sitting at Blantyre, Criminal Case Number 359 of 2009: Republic vs Steven Monjeza Soko And Tiwonge Chimbalanga Kachepa" (Judgement

Pronounced in Open Court at Blantyre, Republic Of Malawi, 20 May, 2010.)

VINCENT, L.

2006 - "Destined to Come to Blows? Race and Constructions of 'Rational-Intellectual' Masculinity

Ten Years After Apartheid", Men and Masculinities 8 (3): 350-366.

WALKER, L.

2005 - “Men Behaving Differently: South African Men since 1994”, Culture, Health \& Sexuality 7 (3): 225-238.

\section{NOTES}

1. For the purposes of this paper, Black and African are used interchangeably to refer to what apartheid law called "a native" and defined as "a person who in fact is or is generally accepted as a member of any aboriginal race or tribe of Africa" (UNION OF 
SOUTH AFRICA 1950: 277). In addition to native, Black and African, these persons were also labeled non-European and Bantu under various pieces of legislation, as well as categorized as members of different tribes or ethnic groups. For readers unfamiliar with the history of South Africa, under the Population Registration Act of 1950 apartheid legislators categorized the population into three categories. Besides the "native", apartheid defined a White person as "a person who in appearance obviously is, or who is generally accepted as a white person, but does not include a person who, although in appearance obviously a white person, is generally accepted as a coloured person" (ibid.: 277). A coloured person was said to be "a person who is not a white person or a native" (ibid.). Asians/Indians were at first categorized under the coloured group under this law.

2. Homicidal, lethal, deadly and fatal interpersonal violence are used interchangeably in the article, and taken to mean death deliberately inflicted on a person by another person or persons.

3. The South African police annual crime report 2009-2010 indicated that the highest rates of murder during the period were in the more rural province of Eastern Cape, with the Western Cape and KwaZulu-Natal the next worst affected (SAPS 2010).

4. Aelred Stubbs, in віко (2004: 80).

5. Make the country "ungovernable" was one of the slogans of the mass democratic movement in South Africa which was a broad of front of groups and individuals against apartheid.

\section{ABSTRACTS}

Homicidal violence is a masculine enterprise, overwhelmingly undertaken against males by other males. Black young men are the most likely victims. Among several posited explanations for the vulnerability of members of this group to fatal is the legacy of apartheid segregation, a weak criminal-justice system and, of special interest here, hegemonic masculinity. This paper argues that while they may be perceived to subscribe to hegemonic masculinity, young Black men are objectively subordinated to this very form of masculinity. This ambiguous positioning of African young men within the labyrinthine racist, patriarchal, capitalist, homophobic structure calls for better explanations. I argue for a closer look at the underappreciated yet crucial role of African men's emotional lives as critical political, social and health issues when dealing with susceptibility to homicide violence. I explore the historical necessity and trade-off of fear and fearlessness in the make-up of dominant Black masculinity. I posit that analyses of Black men's violent death have to incorporate analyses of structures, and yet will likely fail in transforming dominant forms of Black masculinity where they neglect the emotional existence of Black men.

En Afrique du Sud, la violence homicide est une œuvre masculine, très majoritairement portée par des hommes contre d'autres hommes. Les plus exposés à cette violence sont les jeunes hommes noirs. Parmi les explications avancées concernant la vulnérabilité de ce groupe, on trouve l'héritage de la ségrégation durant l'apartheid, un système judiciaire déficient et, de manière plus intéressante, la masculinité dite hégémonique. Dans cet article, il est montré que 
bien qu'ils puissent être perçus comme souscrivant à la masculinité hégémonique, les jeunes hommes noirs sont objectivement subordonnés à cette forme de masculinité. Le positionnement ambigu des jeunes hommes africains dans le cadre de cette structure labyrinthique raciste, patriarcale, capitaliste et homophobe appelle de meilleures explications. Je propose d'examiner de plus près le rôle sous-évalué et pourtant crucial de la vie émotionnelle des hommes africains, en la considérant comme question politique, sociale et sanitaire dès lors qu'elle est reliée à la violence homicide. J'explore le compromis historique entre la peur et l'intrépidité dans la fabrique de la masculinité noire dominante. J'avance que la compréhension des morts violentes d'hommes noirs doit reposer sur des analyses structurelles, et qu'elle ne pourra contribuer à transformer les formes dominantes de la masculinité noire si elle néglige les existences émotionnelles des hommes noirs.

INDEX

Mots-clés: Afrique du Sud, hommes noirs, homicide, masculinité, violence

Keywords: South Africa, Black Men, Homicide, Masculinity, Violence

\section{AUTHOR}

\section{KOPANO RATELE}

Institute for Social and Health Sciences, University of South Africa/Medical Research CouncilUniversity of South Africa's Safety and Peace Promotion Research Unit. 